\title{
The influence of laser irradiation on the development of vegetative mycelium Pleurotus ostreatus
}

\author{
Kateryna Reshetnyk, \\ Yuriy Prysedsky, \\ Dmytro Yuskov \\ Department of Plant Physiology \\ and Biochemistry, \\ Vasyl'Stus Donetsk National University, \\ 600-richya St. 21, \\ Vinnytsia 21021, Ukraine
}

\begin{abstract}
The article presents the results of the study on the influence of laser irradiation on the development of vegetative mycelium and the period of the occurrence of the corcules of the fruit bodies of Pleurotus ostreatus. It has been established the growth processes of $P$. ostreatus, can be best stimulated by applying laser irradiation of mycelium with a green spectrum of light for $10 \mathrm{~s}$. According to this mode of exposure, the best increase in the growth rate of mycelium of $38.3 \%$ and the appearance of the largest number of rudiments of the fruiting bodies were recorded. Laser irradiation of mycelium for $10 \mathrm{~s}$ with red and blue light spectrum increased the growth rate of mycelium from 7.41 to $20.4 \%$, respectively, and the number of rudiments of the fruiting bodies increased by 1.5 to 2 times. Laser irradiation of the mycelium with $5 \mathrm{~s}, 15 \mathrm{~s}$, and $20 \mathrm{~s}$ with red, blue, and green light spectra did not have a significant effect on the growth processes of $P$. ostreatus. These data open significant prospects for the modification of the existing cultivation technologies, which would increase the economic efficiency of the biotechnological cultivation process of $P$. ostreatus.
\end{abstract}

Keywords: basidium mushrooms, laser irradiation, photoactivation, Pleurotus ostreatus

\section{INTRODUCTION}

After Agaricus bisporus, Pleurotus ostreatus is known as the second most cultivated species of edible fungi in the world. Due to the ability of the Pleurotus genus to grow on a variety of lignocellulosic wastes, their cultivation can be an effective technology for the processing of organic

\footnotetext{
*Corresponding author. Email: k.reshetnyk@donnu.edu.ua
}

waste products in agriculture, which would enable the production of protein-rich products and contribute to the reduction of environmental pollution (Bhattacharjya et al., 2015; Figlas et al., 2016). On the other hand, the use of fungi as food will overcome the deficiency of protein in the developing countries. Relying on standard mushroom cultivation techniques, researchers add new technological components to this process that allow shortening the cultivation time, increasing the yield and the quality of the fruiting 
bodies. However, the solution of these issues is impossible without the use of knowledge on the physiology of fungi, combined with information on the environmental factors that affect the growth and development of macromycetes (Tisch, Schmoll, 2010).

One of these factors is the light that regulates morphogenetic processes in many types of fungi, although they are not phototrophic organisms. The nature of the effect of light depends on its spectral characteristics and the duration of the light (Kamada et al., 2010). Mushrooms can absorb almost ultraviolet, blue, green, red, and distant red light, using up to 11 photoreceptors and signalling cascades to control most of the genome and adapt to environmental conditions (Zhenzhong, Reinhard, 2018). Recently, the mechanisms of the photoreceptor of fungi have attracted intensive research (Kritskiy et al., 2010; Tisch, Schmoll, 2010; Poyedinok, 2015). Several types of photoreceptors in mushrooms were described (Herrera-Estrella, Horwitz, 2007). Thus, in the basidymicetes Coprinus cinereus, Pleurotus ostreatus, and Lentinula edodes the genes encoding the receptors responsible for the perception of blue light were found. The study into the fungal genome revealed the photoreceptor genes encoding proteins that are sensitive to red light (Kamada et al., 2010). The green light is perceived by opsin systems based on retinal, the biological functions of which still need to be clarified (Zhenzhong, Reinhard, 2018). The use of artificial light to stimulate biological processes in fungi is limited by the methods that require prolonged illumination of crops at different stages of morphogenesis, which leads to additional energy expenditure.

On the other hand, studies conducted by Karu at the cellular level for some biological objects showed that short-term irradiation (a few seconds) with low-intensity light in relatively small doses $\left(102-103 \mathrm{~J} / \mathrm{m}^{2}\right)$ contributes to a long-lasting macro effect (Karu, 1986). The positive influence of UV and $\gamma$ irradiation on the yields of $P$. ostreatus fungus was also investigated, and it was found that laser irradiation at doses of $45-230 \mathrm{~mJ} / \mathrm{cm}^{2}$ stimulated sprout growth and mycelium growth in Hericium erinanceus. The known influence of lowintensity light on the linear growth and biomass accumulation by different types of macromycetes (Agaricus bisporus, Inonotus obliguus, Ganoderma lucidium, Hericium erinanceus, and Lentinula ededes) (Poyedinok et al., 2013). According to Poyedinok, at different stages of ontogenesis, macromycetes are sensitive to low-intensity light in the visible wavelength range with different spectral and energy characteristics (Poyedinok, 2015). According to modern mechanisms of photoregulation of living organisms, photochemical reactions occur due to the excitation of electrons in the atoms of the absorbing light of matter. At the molecular level, this is expressed as photoionization of matter, its reduction, photooxidation, photodissociation of molecules, and their reorganisation - photoisomerization (Karu et al., 1994). Analysis of the results of research on photoreceptor mechanisms in mushrooms obtained by local and foreign scientists proves the possibility of using laser radiation in order to increase the biological activity of cultivated macromycetes, to stimulate their growth and intensify the technological stages of cultivation. Nonetheless, the above methods of intensifying growth processes are complex in terms of practical use, since they require the use of stationary laser installations, argon and helium-neon lasers that have significant energy intensity, large dimensions and masses. LED lasers, which have high efficiency (up to 50\%), speed (up to $10-11 \mathrm{~s}$ ), comfort of excitation, the possibility of generating radiation with the required wavelength, small dimensions and technological compatibility with elements of optical integrated circuits are much more effective for the intensification of metabolic processes of macromycetes (Vasiura, 1998). Also, they are low cost and require little power consumption when applied. However, the literature data on the influence of LED laser systems on the parameters of fungal growth are limited, thus this issue requires further study. The purpose of the work was to investigate the effect of laser irradiation on the development of vegetative mycelium 
and the period of the appearance of the buds of the fruiting bodies of $P$. ostreatus.

\section{MATERIALS AND METHODS}

The P-192 strain of Pleurotus ostreatus (Jacq.:Fr.) Kumm mushroom from the collection of cabbage mushrooms of the Department of Plant Physiology and Biochemistry of Vasyl' Stus Donetsk National University was studied. The strain under research was isolated in a pure culture of wild-growing fruiting bodies of basidium mushrooms collected in different areas of the Donetsk region. In order to study the effect of laser irradiation on the development of the vegetative mycelium of the $P$. ostreatus fungus, the strain P-192 was cultivated for seven days in standard wort-agar environment $\left(4^{\circ}\right.$ by Baling) in standard Petri dishes $(9 \mathrm{~cm}$ in diameter), prior to the inoculation of mycelia in Petri dishes separated by a sterile steel tube into pieces $5 \times 5 \mathrm{~mm}$ in size. Then each inoculum was irradiated with LED lasers: BRP-3010-5 with a $635 \mathrm{~nm}$ red wavelength radiation, BBP-30105 with the radiation of the blue spectrum at $a$ wavelength of $405 \mathrm{~nm}$, and BGP-3010-5 with the green spectrum of radiation at a wavelength of $532 \mathrm{~nm}$ (BOB LASER Co., China). The power of each laser was $100 \mathrm{~mW}$. The density of the energy of laser irradiation was calculated by Vakarchuk (Vakarchuk, 2012). The energy dose of irradiation (the energy of light falling into the unit area) was determined as the product of the energy density and the time of irradiation. In all variants of the experiment, the irradiation energy was within the range of $25-102.5 \mathrm{~mJ} /$ $\mathrm{cm}^{2}$. This value was selected according to the results of the literature (Poyedinok, 2015). Irradiation of mycelium was carried out in keepeing with the scheme presented in Table 1. Unsaturated mycelium was used for control culturing. Surface cultivation of mycelium $P$. ostreatus was carried out in a thermostat at $a$ temperature of $26^{\circ} \mathrm{C}$ in a standard wort-agar medium $\left(4^{\circ} \mathrm{Bal}-\right.$ ing). Each day of the cultivation period, the radius of the colonies on the media in Petri dishes was measured in four perpendicular directions. The presence of "buckles" - specific morpholog-
Table 1. The scheme of irradiation of mycelial fungus $P$. ostreatus

\begin{tabular}{c|c|c|c|c}
\hline \multirow{2}{*}{$\begin{array}{c}\text { Sample } \\
\text { variant }\end{array}$} & \multicolumn{3}{|c|}{$\begin{array}{c}\text { Duration of irradia- } \\
\text { tion, s }\end{array}$} & $\begin{array}{c}\text { Energy of } \\
\text { irradiation, } \\
\text { mJ/.cm }\end{array}$ \\
\cline { 2 - 4 } & Red & Blue & Green & 0 \\
\hline 1 & 0 & 0 & 0 & 25.05 \\
\hline 2 & 5 & 0 & 0 & 25.05 \\
\hline 4 & 0 & 5 & 0 & 25.05 \\
\hline 5 & 0 & 0 & 5 & 51.1 \\
\hline 6 & 10 & 0 & 0 & 51.1 \\
\hline 7 & 0 & 10 & 0 & 51.1 \\
\hline 8 & 15 & 0 & 0 & 77.3 \\
\hline 9 & 0 & 15 & 0 & 77.3 \\
\hline 10 & 0 & 0 & 15 & 77.3 \\
\hline 11 & 20 & 0 & 0 & 102.5 \\
\hline 12 & 0 & 20 & 0 & 102.5 \\
\hline 13 & 0 & 0 & 20 & 102.5 \\
\hline & & & & \\
\hline
\end{tabular}

ical formations on the P. ostreatus hyphae - was determined by microscopic control. After complete overgrowth of Petri dishes with mycelium, they were transferred to a growth chamber at a temperature of $12-16^{\circ} \mathrm{C}$ to be tested for the ability to form the buds of the fruiting bodies (primordia).

Based on the obtained data, the average daily gain of mycelium, the average speed of the radial growth $(\mathrm{mm} /$ day), the time interval before the formation of primordia (number of days), and the average number of primordia per Petri dish were determined. In order to evaluate the growth of the cultures, a method based on the study and analysis of the dynamics of increasing the radius of colonies from the time of cultivation was applied (Bysko et al., 1983).

All the necessary experiments were replicated three times. The method of dispersion analysis was applied to determine the probability of exposure to laser irradiation. The comparison of the mean values was based on the Dunnet method. The processing was carried out using a package of statistical programs designed at the Department of Plant Physiology and Biochemistry of the Donetsk Vasyl' Stus National University (Prysedskyy, 2005). 


\section{RESULTS AND DISCUSSION}

Since the photoreceptor system of mushrooms is known to be adapted to light in the range of wavelengths from 350 to $730 \mathrm{~nm}$ (Corrochano, 2007), this spectral row is represented by the wavelengths chosen by us (red, blue and green spectra). The results of the research demonstrate the positive effect of laser irradiation on the development of vegetative mycelium of the studied strain $P$. ostreatus. The response to irradiation varied according to the spectral characteristics of light and the duration of exposure (Table 2).

From day 3 of cultivation, a significant probable difference was observed in the growth of micelles irradiated with red (Option 5), blue (Option 6), and green (Option 7) light for $10 \mathrm{~s}$ compared to non-irradiated mycelium (Option 1). In particular, the average daily gain of mycelium was $3.27,2.76$, and $3.72 \mathrm{~mm}$ respectively, i.e., these figures exceeded the control figures by $32.7 \%, 27.6 \%$, and $37.2 \%$, respectively. Laser irradiation of mycelium for $5 \mathrm{~s}$ in the 2 nd and 3 rd experimental variants accelerated the average daily gain of the mycelium of the investigated strain by $1.42 \mathrm{~mm}$ (red spectrum of irradiation), $1.91 \mathrm{~mm}$ (blue irradiation spectrum), and $1.61 \mathrm{~mm}$ (green spectrum of irradiation) compared with the control sample. Laser irradiation of mycelium for $15 \mathrm{~s}$ with red, blue and green spectra probably increased mycelium growth by only $14.8 \%$ (option 8 ) and $12.7 \%$ (options 9 and 10), respectively. Because of irradiation of mycelium for $20 \mathrm{~s}$, no significant change in average daily sprout was observed. On day 4 of cultivation, a significant increase in mycelium was observed because of laser irradiation for $10 \mathrm{~s}$ with the green light: by $38.3 \%$ more than the control sample. The reaction in response to the effect of the red and blue light spectra at the same duration of exposure was quite high: the average daily gain of mycelium increased by $28.5 \%$ and $21.5 \%$, respectively. Micellar irradiation for 5, 15, and 20 seconds did not cause significant changes in mycelium growth. For the effects of green (variant 7) irradiation with a duration of $10 \mathrm{~s}$ already for 8 days of cultivation, the radius of the colonies reached $45.05 \mathrm{~mm}$, which is $19.2 \%$ more than the control sample. The Petri dishes were completely overgrown with mycelium. In other

Table 2. Increase of the radius of $\boldsymbol{P}$. ostreatus colonies due to laser irradiation

\begin{tabular}{|c|c|c|c|c|c|}
\hline \multirow{3}{*}{ Sample variant } & \multicolumn{5}{|c|}{ Age of the colony, days } \\
\hline & 2 & 3 & 4 & 8 & 9 \\
\hline & \multicolumn{5}{|c|}{ Radius of colonies, $\mathrm{mm}$} \\
\hline 1 & $5.42 \pm 0.13$ & $10.05 \pm 0.25$ & $14.34 \pm 0.14$ & $37.81 \pm 0.34$ & $43.02 \pm 0.11$ \\
\hline 2 & $5.63 \pm 0.18^{\star}$ & $11.42 \pm 0.26^{*}$ & $14.83 \pm 0.14^{\star}$ & $38.13 \pm 0.36^{*}$ & $44.96 \pm 0.28^{\star}$ \\
\hline 3 & $5.82 \pm 0.26^{\star}$ & $11.91 \pm 0.42^{*}$ & $14.81 \pm 1.06^{*}$ & $37.86 \pm 0.28^{*}$ & $44.54 \pm 0.46^{\star}$ \\
\hline 4 & $5.84 \pm 0.13^{\star}$ & $11.62 \pm 0.37^{\star}$ & $14.86 \pm 0.88^{\star}$ & $38.93 \pm 0.43^{*}$ & $44.06 \pm 0.41^{\star}$ \\
\hline 5 & $6.92 \pm 0.21^{\star}$ & $13.27 \pm 0.45^{\star}$ & $18.44 \pm 0.07^{\star}$ & $42.04 \pm 0.25^{\star}$ & $45.04 \pm 0.53^{\star}$ \\
\hline 6 & $6.44 \pm 0.32^{*}$ & $12.76 \pm 0.48^{\star}$ & $17.43 \pm 0.41^{\star}$ & $39.66 \pm 0.42^{*}$ & $45.09 \pm 0.42$ * \\
\hline 7 & $6.02 \pm 0.71^{\star}$ & $13.72 \pm 0.27^{\star}$ & $19.83 \pm 0.21^{*}$ & $45.05 \pm 0.43^{*}$ & $45.06 \pm 0.12^{*}$ \\
\hline 8 & $6.05 \pm 0.24^{*}$ & $11.54 \pm 0.49^{*}$ & $15.15 \pm 0.28^{\star}$ & $38.74 \pm 0.27^{\star}$ & $44.34 \pm 0.13^{*}$ \\
\hline 9 & $5.94 \pm 0.24^{\star}$ & $11.33 \pm 1.03^{*}$ & $15.93 \pm 0.31^{\star}$ & $37.86 \pm 0.29^{*}$ & $44.64 \pm 0.25^{\star}$ \\
\hline 10 & $5.82 \pm 0.32^{\star}$ & $11.32 \pm 0.41^{\star}$ & $15.66 \pm 0.31^{\star}$ & $38.04 \pm 0.17^{\star}$ & $45.04 \pm 0.15^{\star}$ \\
\hline 11 & $5.03 \pm 0.14^{\star}$ & $10.34 \pm 0.21^{\star}$ & $14.74 \pm 0.21^{\star}$ & $36.88 \pm 0.46^{*}$ & $43.08 \pm 0.42^{*}$ \\
\hline 12 & $5.86 \pm 0.27^{\star}$ & $10.14 \pm 0.41^{\star}$ & $14.93 \pm 0.32^{*}$ & $36.54 \pm 0.35^{\star}$ & $42.06 \pm 0.21^{\star}$ \\
\hline 13 & $5.66 \pm 0.16^{*}$ & $10.93 \pm 0.12^{*}$ & $14.29 \pm 0.24^{*}$ & $37.86 \pm 0.48^{\star}$ & $42.09 \pm 0.43^{\star}$ \\
\hline
\end{tabular}

Note. ${ }^{*}$ - the difference is statistically significant compared to the control variant $(P<0.05)$, (variants of the experiment according to Table 1). 
variants of radiation, the change in the radius of colonies of mycelium was negligible and only for the effects of red and blue laser irradiation this figure increased by $11.2 \%$ and $4.5 \%$, respectively.

We found out that laser irradiation positively influenced the average rate of the radial growth of mycelial $P$. ostreatus. Thus, for the effects of red laser irradiation of mycelium for $10 \mathrm{~s}$, the average speed of radial growth was $20.4 \%$ higher than the control ones, while the effects of exposure to the blue spectrum increased by 7.4\% (Fig. 1).

The best growth was recorded as a result of irradiation with the green light for 10 seconds, the average speed of the radial growth exceeded the control sample by $27.8 \%$. Laser irradiation of micelles for $5 \mathrm{~s}, 15 \mathrm{~s}$, and $20 \mathrm{~s}$ with red, blue, and green light spectra did not have a significant effect on the growth processes of P. ostreatus.

The next stage of our research was the study of the effect of laser irradiation of mycelium on the formation of the buds of the fruiting bodies (primordia). The appearance of the buds was recorded as early as dya 13 of cultivation in almost all variants of experiment, including the control one. In the dishes with unpexed mycelium, the first primordia appeared on day 15 of cultivation. On day 13 of cultivation, most of the primordia (nine pieces) were formed under the effects of laser irradiation with the green spectrum of light for $10 \mathrm{~s}$. Irradiation with red and blue light for $10 \mathrm{~s}$ contributed to the formation of primordia in six pieces. Under the effect of laser irradiation of mycelium for $5 \mathrm{~s}$ and $15 \mathrm{~s}$ of red, blue, and green light, there were 5-6 pieces of primordia. For these modes of micellar irradiation for $20 \mathrm{~s}$, the number of rudiments of the foetal bodies was insignificant (1-3 pieces). On day 15 of cultivation, the largest number of primordia was formed under the action of radiation for $10 \mathrm{~s}$ with the green light $-180.2 \%$ more than the control ones. Irradiation with the red and blue light for $10 \mathrm{~s}$ increased the number of primordia from $80.3 \%$ to $120.4 \%$, respectively. Laser irradiation of mycelium over $5 \mathrm{~s}$ and $15 \mathrm{~s}$ with red, blue and green light increased the number of formed primordia from 40.3 to $60.4 \%$, respectively. Under the effects of radiation for $20 \mathrm{~s}$, the number of primordia was almost the same as in the control sample. On day 18 of cultivation, the maximum number of buds of the fruiting bodies was recorded under the irradiation of mycelium for $10 \mathrm{~s}$ with the green spectrum of light, which is $137.5 \%$ higher than the control sample. Micellar irradiation for $5 \mathrm{~s}, 15 \mathrm{~s}$, and $20 \mathrm{~s}$ with red, blue and green light spectra increased the number of primordia by 1.5-2 times. On day 21 of cultivation, the largest number of primordia (26 pieces) was formed due to laser irradiation of mycelium with the green light for $10 \mathrm{~s}$. The irradiation with blue and red light for $10 \mathrm{~s}$

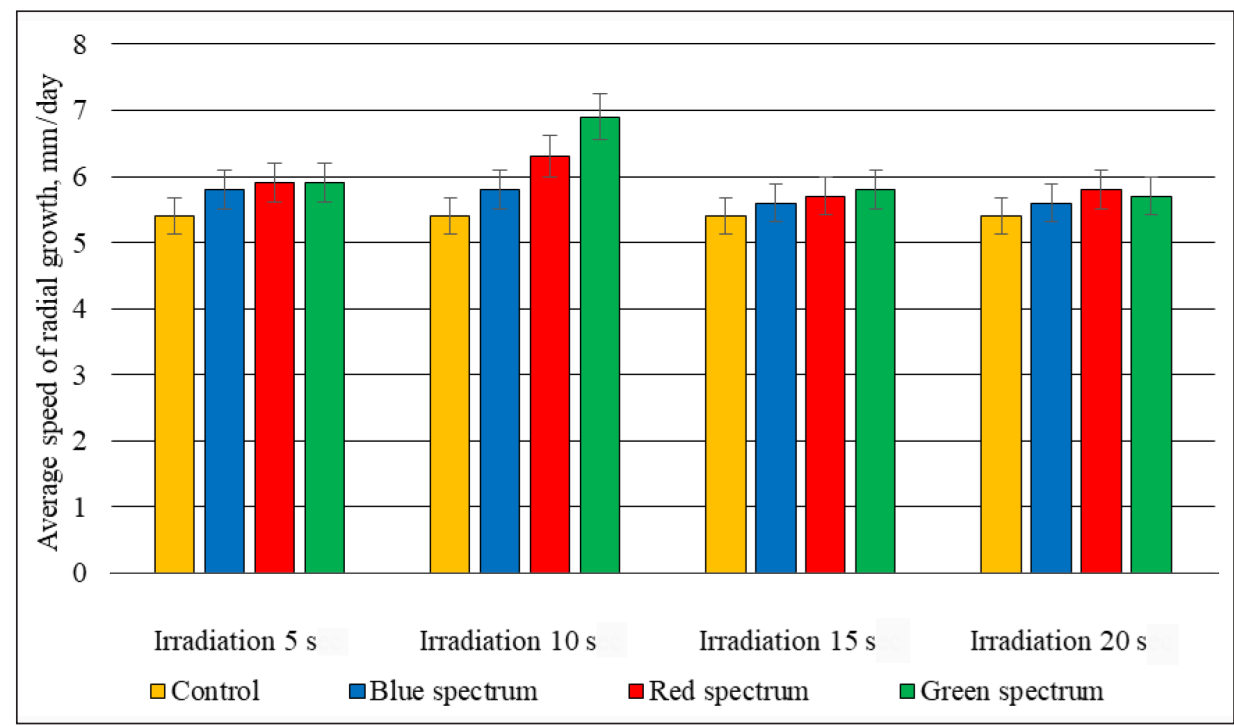

Fig. 1. Influence of laser irradiation on the average rate of the radial growth of P. ostreatus mycelium 
increased the number of primordia by $46.1 \%$ and $38.4 \%$, respectively. In other studied modes of exposure, the number of primordia increased from 23.5 to $30.1 \%$ (Fig. 2).

When irradiated for $20 \mathrm{~s}$, the number of primordia almost did not exceed the control sample. On day 24 of cultivation, the most buds of the fruiting bodies formed due to the effects of green laser irradiation that lasted for $10 \mathrm{~s}$; their number was $73.7 \%$ higher than the control variant. Laser irradiation with the blue light for $10 \mathrm{~s}$ contributed to an increase in the number of primordias by $36.8 \%$ compared to the control variant. Irradiation with the red spectrum increased the number of buds of fruiting bodies by $26.3 \%$. The irradiation of mycelium for $5 \mathrm{~s}$ and $15 \mathrm{~s}$ with red, blue and green spectra increased the number of primordia by $15.8-26.3 \%$. Under irradiation of mycelium for $20 \mathrm{~s}$, a small difference was found between the number of buds of the fruiting bodies compared with the control variant.

It was established that laser irradiation affects the growth processes of $P$. ostreatus. The reaction in response to the laser exposure depends on the duration of exposure and the spectrum of light. The effect of green laser irradiation that lasted for $10 \mathrm{~s}$ is the most effective. In this mode of exposure, the best increase in the growth rate of mycelium was found to be $38.3 \%$, and the greatest number of buds of the fruiting bodies appeared. Laser irradiation with red and blue spectra increased the average radial growth rate from $7.4 \%$ to $20.4 \%$, respectively, and the number of buds of the fruiting bodies increased by 1.5- 2 times, respectively. The irradiation of mycelium that lasted for $5 \mathrm{~s}, 15 \mathrm{~s}$, and $20 \mathrm{~s}$ did not have a significant effect on the growth processes of $P$. ostreatus. The results of our research coincide with the literature data (Doroshkevich, 2007 Poyedinok, 2015). Responses to the action of laser irradiation are associated with the changes in the parameters of cellular homeostasis, and they fit into the theory of universal mechanisms of photostimulation. According to this theory, the main physical or chemical changes caused by exposure to photoconceptor molecules are accompanied by a cascade of biochemical reactions in cells that do not require further activation by light (Karu et al., 1994). The stimulation of growth processes for the production of uterine and sown micelles is crucial in the cultivation of macromycetes, since it reduces the probability of pathogenic microflora contamination with mycelium and improves its adaptive properties.

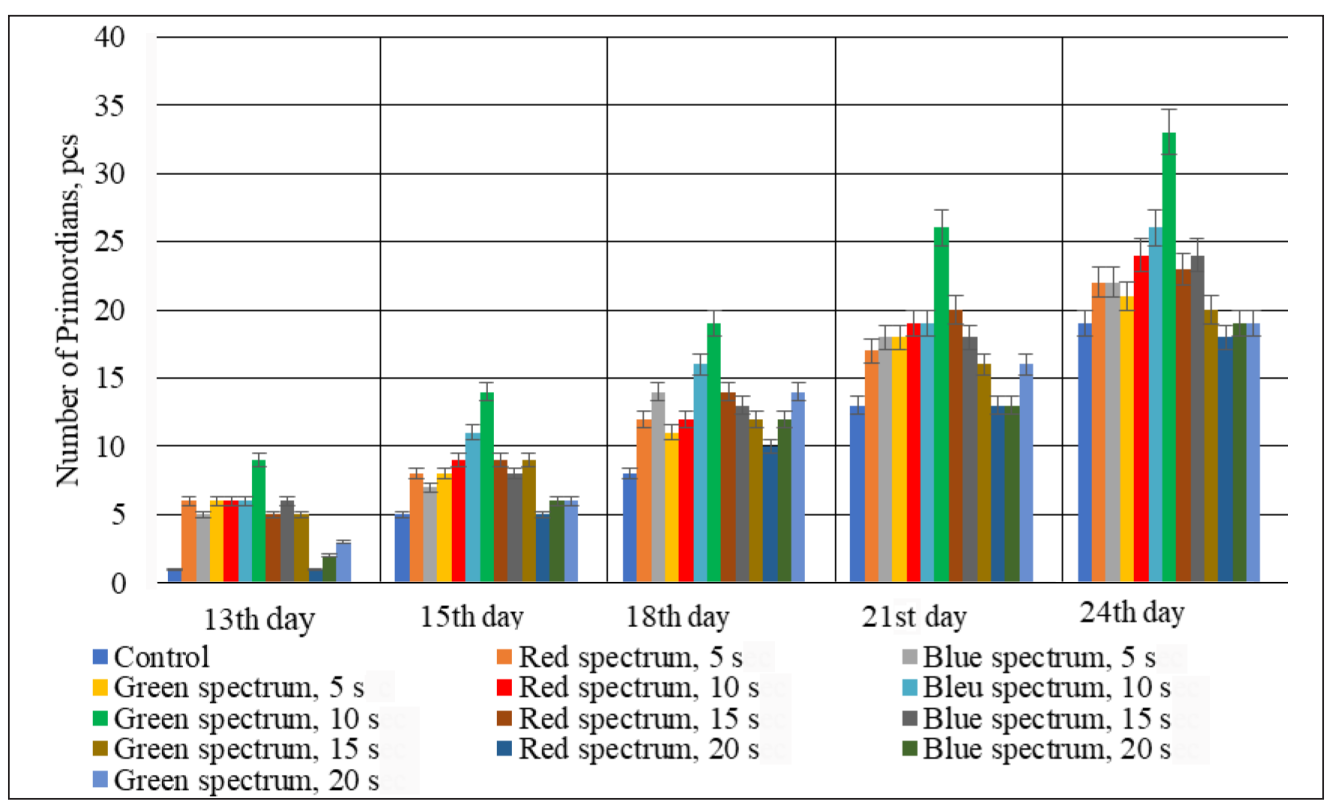

Fig. 2. The effect of laser irradiation on the period of appearance and the number of rhizomes of the fruiting bodies of P. ostreatus (variants of the experiment according to Table 1) 


\section{CONCLUSIONS}

The research validates the fact that the best way to stimulate $P$. ostreatus growth processes, is to apply laser irradiation of mycelium with the green light spectrum for $10 \mathrm{~s}$. The effect of this irradiation regime resulted in a maximum increase in the growth rate of mycelium by $38.3 \%$ and the appearance of the largest number of buds of the fruiting bodies. Laser irradiation of mycelium for $10 \mathrm{~s}$ with red and blue light spectra increased the growth rate of mycelium from $7.4 \%$ to $20.4 \%$, respectively, and the number of buds of the fruiting bodies increased by 1.5 - 2 times. Laser microwave irradiation for $5 \mathrm{~s}, 15 \mathrm{~s}$, and $20 \mathrm{~s}$ with red, blue and green spectra of light did not significantly affect the growth processes of $P$. ostreatus. These data open significant prospects for the modification of existing cultivation technologies, which would increase the economic efficiency of the process of biotechnological cultivation of P. ostreatus.

Received 19 June 2019 Accepted 8 November 2019

\section{References}

1. Bhattacharjya DK, Paul RK, Miah Md. N, Ahmed KU. Comparative study on nutritional composition of oyster mushroom (Pleurotus ostreatus Fr.) cultivated on different sawdust substrates. Bioresearch Communications. 2015; 1(2): 93-8.

2. Bysko NA, Bukhalo AS, Vasser SP, Dudka IA, Kulesh MD, Solomko EF, Shevchenko SV. Higher edible basidiomycetes in superficial and deep culture. Kiev: Scientific opinion; 1983. Ukrainian.

3. Corrochano LM. Fungal photoreceptors sensory molecules for fungal development and behaviour. Photochem Photobiol Sci. 2007; 6(7): 725-36.

4. Doroshkevich NV. Influence of laser irradiation on fungus productivity Pleurotus ostrea- tus (Jacq.:Fr.) Kummer. Bulletin of Donetsk National University. 2007; 1: 290-2.

5. Figlas ND, Matute G, Curvetto N. Sunflower seed hull: its value as a broad mushroom substrate. Ann Food Process Preserv. 2016; 1(1): 1002.

6. Herrera-Estrella A, Horwitz BA. Looking through the eyes of fungi: molecular geneticsof photoreception. Mol Microbiol. 2007; 64(1): 5-15.

7. Kamada T, Sano H, Nakazawa T, Nakahori K. Regulation of fruiting body photomorphogenesis in Coprinopsis cinerea. Fungal Genet Biol. 2010; 47(11): 917-21.

8. Karu T, Tiphlova O, Esenaliev R, Letokhov V. Two different mechanisms of low intensity laser photobiolgical effect on Escherichia coli. Photochem Photobiol Biol. 1994; 24(3): 155-61.

9. Karu TI. On the molecular mechanism of therapeutic action of low-intensity laser radiation. Dokl Akad Nauk SSSR. 1986; 291(5): 1245-9. Russian.

10. Kritskiy MS, Telegina TA, Vechtomova YL, Kolesnikova MP, Lyudnikova TA, Golub OA. Photoexcited molecules of flavin and pterin coenzymes in evolution. Biochemistry. 2010; 75(10): 1348-66.

11. Poyedinok NL. The use of artificial light in mushroom cultivation biotechnologies. Biotechnology Acta. 2013; 6(6): 58-70.

12. Poyedinok NL, Myhaylova OB, Hodakovskyy VM, Dudka IA. Influence on growth activity of the seed material of cultivated macromycetes of low-intensity laser radiation. Microbiology and biotechnology. 2015; 29(1): 77-86.

13. Prysedskyy YG. Software package for statistical processing of the results of the biological experiments. Donetsk: DonNU 2005, 84 p. Ukrainian.

14. Tisch D, Schmoll M. Light regulation of metabolic pathways in fungi. Appl Microbiol Biotechnol. 2010; 85(5): 1259-77. 
15. Vakarchuk IO. Quantum mechanics: a textbook. Lviv: Ivan Franko LNU; 2012. 872 p. Ukrainian.

16. Vasiura AS. Elements and devices of automation control systems. Vinnytsia: VDTU; 1998. 420 p. Ukrainian.

17. Zhenzhong Yu, Reinhard F. Light sensing and responses in fungi. Nature Reviews Microbiology. $2018 ; 17(1): 25-36$.

\section{Kateryna Reshetnyk, Yuriy Prysedsky,} Dmytro Yuskov

\section{LAZERIO SPINDULIUOTĖS POVEIKIS GLUOSNINĖS KREIVABUDĖS PLEUROTUS OSTREATUS GRYBIENAI}

\section{Santrauka}

Straipsnyje pateikiami lazerio spinduliuotès poveikio vegetatyviniam grybienos vystymuisi ir Pleurotus ostreatus vaisiakūnių formavimuisi tyrimų rezultatai. Nustatyta, kad norint stimuliuoti $P$. ostreatus augimo procesus, geriausia grybieną 10 sek. veikti žalios šviesos spektro spinduliuote. Taikant ši būdą buvo užfiksuotas ryškus grybienos augimo greičio padidejjimas $(38,3 \%)$ ir didžiausias vaisiakūnių užuomazgų skaičius. Paveikus grybieną raudonos ir mèlynos šviesos lazeriu 10 sek., grybienos augimo greitis padidejo atitinkamai 7,41 ir 20,4 \%, o vaisiakūnių užuomazgų skaičius išaugo 1,5-2 kartus. Lazerinè spinduliuote raudonos, mėlynos ir žalios šviesos spektru 5 sek., 15 sek. ir 20 sek. neturejo reikšmingo poveikio $P$. ostreatus augimo procesams. Šie duomenys atveria didelę esamų auginimo technologijų modifikavimo perspektyvą, o mūsų tiriamuoju atveju patvirtina P. ostreatus biotechnologinio auginimo proceso didesnį ekonominị efektyvumą.

Raktažodžiai: papėdgrybiai, lazerio spinduliuotès poveikis, fotoaktyvinimas, Pleurotus ostreatus 